\title{
Natural fiber thermoplastic composites in terms of new production technologies: A review
}

\section{Yeni imalat teknolojileri açısından doğal elyaf termoplastik kompozitler: Bir derleme}

\author{
Anıl AKDOĞAN ${ }^{1 *}$ iD, Ali Serdar VANLI' iD \\ 1,2Mechanical Engineering Department, Faculty of Mechanical Engineering, Yildiz Technical University, Istanbul, Turkey. \\ nomak@yildiz.edu.tr, svanli@yildiz.edu.tr
}

Received/Geliș Tarihi: 23.11.2018, Accepted/Kabul Tarihi: 17.06.2019

* Corresponding author/Yazışılan Yazar

doi: $10.5505 /$ pajes.2019.04864

Review Article/Derleme Makalesi

\begin{abstract}
This paper investigates Natural Fiber Thermoplastic Composites (NFTC) which take attention of the researchers and the market having aesthetic and low maintenance properties in many applications. Additive usage is an increasing application for NFTC production to get into the novel markets satisfying strong performance requirements and life stability interests of users. In this article, polymer blends from natural resources including bio-based additives for polymer composites were introduced. Afterwards, favorite additive types and most effective pelletizing processes in literature were analyzed to improve composite productivity. At the end of the paper, the common NFTC production technologies are discussed. A specially designed compounding extruder which is designed to overcome production difficulties and supply high processing performances is introduced. At the end of conducted experiment, the obtained production output rate is presented.
\end{abstract}

Keywords: Polymer composites, Natural fiber thermoplastic composites, Manufacturing technologies, Productivity

\section{Introduction}

During the last four decades, renewable resourced polymers have been taking great attention due to the environmental concerns. Compostable and biodegradable plastics which are based on renewable resources from the agricultural environments were a basic innovation. Waste problems and $\mathrm{CO}_{2}$ emissions originated environmental problems are the main reasons for biopolymers being a primarily interests of the researchers to create better alternatives to conventional materials [1]. Natural fiber reinforcement has gained attention in polymers as a result of increasing cost of petroleum products. These materials are described under the name of Natural Fiber Thermoplastic Composites (NFTC).

Common natural resources which are being widely used for polymer composite production can be obtained from various resources e.g. fruit, seed, leaf, grasses, wood and bast. These fibers are cheap and have good specifications that are comparable to synthetic ones. They show very good mechanical specifications such as stiffness, flexibility and elastic modulus against glass fibers [2]. For instance, wood fibers are widely used biodegradable fillers. As matrix materials; thermosets like epoxy and polyesters and thermoplastics like Polypropylene (PP) and Polyethylene (PE) which are the common resins in composite products.

According to the Imre B. and Pukánszky B. (2013) natural polymers are one of a basic class of materials in polymer groups
Öz

Bu çalıșma, estetik ve düșük bakım özelliklerine sahip birçok uygulamada araștırmacıların ve pazarın dikkatini çeken Doğal Elyaf Termoplastik Kompozitleri (NFTC) araștırmaktadır. Katkı kullanımı, NFTC üretimi açısından giderek artış gösteren, güçlü performans gereksinimlerini karşıladığı için de yeni pazarlara giriş imkanı sağlayan, uzun ömürlü ve kullanıcı beklentilerini tatmin eden bir uygulamadır. Bu çalıșmada, polimer kompozitlerin biyo-bazlı katkıları dahil olmak üzere doğal kaynaklardan elde edilen polimer karışımlar tanıtılmıștır. Illaveten, kompozit üretkenliğini arttırmak için favori katkı maddeleri ve literatürdeki en etkili peletleme işlemleri analiz edilmiștir. Calıșmanın sonunda, yaygın olarak kullanılan NFTC üretim teknolojileri tartışılmıştır. Çeşitli imalat zorluklarının üstesinden gelen ve yüksek ișlem performansları sağlayan bir imalat için özel olarak tasarlanmıș karıștırıcı bir extruder tanıtılmıștır. Deneysel bir uygulama sonunda ulaşılan üretim kapasitesi paylaşılmıştır.

Anahtar kelimeler: Polimer kompozitler, Doğal elyaf termoplastik kompozitler, İmalat teknolojileri, Verimlilik

of natural resources. They are found in nature as macromolecules. Physically or chemically modified polymers can be included in natural polymers category. The authors defined and classified biopolymers, criticized modification approaches and blend factors, their miscibility and compatibility [3]. Typical examples of natural materials are cellulose, hemicelluloses, lignin, silk and starch. Natural fibers could be oriented from either plant or animal sources. They are classified based on their original type. Firstly, protein can be identified as the basic component of animal fibers like silk and angora fibers, whereas cellulose could be identified as the basic component of plant fibers. Cellulosic/lignocellulosic plant fibers can be categorized as given in the Table 1.

Table 1: Plant fibers categorization.

\begin{tabular}{ccc}
\hline Origin & \multicolumn{2}{c}{ Including but not limited } \\
\hline Seed/fruit & Cotton & Coir \\
Leaf & Sisal & Pineapple \\
Bast & Jute & Keneaf \\
Agricultural & Corn straw/stower & Wheat straw \\
Grass/reed & Switchgrass & Bamboo \\
\hline
\end{tabular}

Excluding cotton, plant based fibers are basically composed of organic components which are water soluble such as waxes, lignin, cellulose and hemicellulose. The chemical compositions of fibers must be analyzed before composite production. Because it could be varied depending on the kind of the biomass [1]. 
Figure 1 gives some examples of common used natural fibers corn straw, saw dust, wood chips.

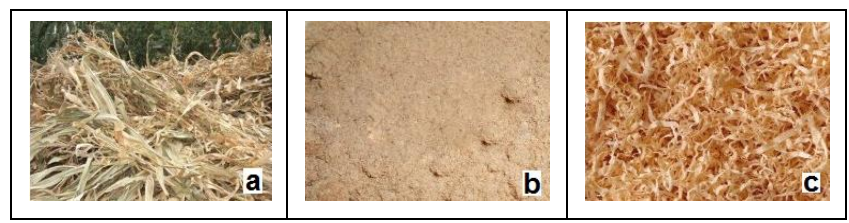

Figure 1: Some natural fibers; (a): Corn straw, (b): Saw dust, (c): Wood chips.

The other material classification is based on the natural or biobased synthetic types that are come into existence from renewable resources. Polylactic acid (PLA) and bio polymers like PE, Polyethylene terephthalate (PET) and Polyamide (PA) can be included in this class. However, bacterial polyesters could be counted as natural materials, because it is produced by fermentation of bacteria [4]. Naseem A. et al. (2016) worked about Lignin-derivatives based polymers, blends and composites and reviewed different types of derivatives of lignin and their possible different applications. They introduced biopolymer lignin blends like protein and starch. Additionally they can be applied in different sectors [5].

Natural fiber usage is growing due to its fiber structure strength, natural abundance, renewability and $\mathrm{CO}_{2}$ neutrality. The researchers are trying to possess high toughness and better insulation capabilities, reduced health damages and tool wear, recyclability, enhanced energy recovery and biodegradability [1]. In recent years, especially wood reinforced composites are very popular in natural fiber polymer composites. Because cellulose is the most abundant renewable bio-polymer on earth and wood contains about $50 \%$ of cellulose [6]. Cellulosic natural fibers like bamboo and hemp, are being used to reinforce polymer matrix. Bamboo fiber addition is increased the tensile strength and tensile modulus besides flexural ones and crystallization rates. Elongations of tensile and flexural ones were also mildly increased at low fiber loadings (<20 wt.\%) [7]. Wood reinforced plastic composites are used much in building products such as decking, fencing, siding, windows, doors and decorative trim. Other applications are in infrastructure e.g. walking boards; in transportation like some panels in automotive, floors of trucks, and in other applications e.g. equipments playgrounds. Moreover, wood reinforced polymer composites are being used in outdoor furniture and outdoor benches already. Wood reinforced composite producers are trying to penetrate into bigger plywood markets and trim board, using its advantages like being light and environmental concerned [8],[9]. Sykacek et al., were aimed in extrusion and injection molding processes of some biocomposites, with different weights of wood flour in it. PLA/PBAT (polybutylene adipate-co-terephthalate)/wood flour composites (including 45/55 wt.\%) were showed an advance in tensile and flexural specifications against the neat polymers [10]. Wood-based filler composites are known to decrease material costs and increase stiffness compared to the neat polymers. It increases ductility and impact strength. In addition, these composites are in general compatible with existing cost-effective processing equipment [11]. The basic disadvantages of wood reinforced polymer composites are water absorbsion aim, weak dimensional consistency, poor fiber-matrix adhesion and original wood fiber characteristic losses in time [12]-[14]. Some other main handicaps against plant fibers are availability, moisture absorption and inconsistency [1]. The inevitable biodegradability of natural polymers is therefore used to prevent premature deterioration. For instance, many natural polymers water solubility character increases degradation rate and degradability. The softening temperature is the other limitation of many natural polymers. Thus, the hydrophilic character of natural polymers has been described as hydrophilic in nature. The novel reactive extrusion process and the used compatibilizers improve interfacial adhesion between natural and synthetic polymers [15]. The need for coupling agents to improve fiber-matrix adhesion in natural fiber filled composites is documented in literature. There are different methods to improve interfacial adhesion were examined. Among them, Maleic anhydride grafted polypropylene (PP-g-MAH) looks as one of the most suitable solution for this problem [11],[16],[17].

Many investigators researched mechanical properties of many kinds of natural fiber composites. For instance; Arrieta M.P. et al. (2013) made a whole characterization of PLA with D-limonene. They were investigated the effect of limonene on mechanical specifications of PLA films. An increase in elongation at break and a decrease in the elastic modulus were observed. A homogeneous surface was observed in all cases by SEM. Due to increased chain mobility supplied by D-limonene, its barrier properties were reduced [18]. Lately, Jorda-Vilaplana A. et al. (2017) worked on characterization of a natural fiber reinforced thermoplastic with "Cortaderia selloana" fibers from Spain. High-Density Polyethylene (HDPE) was consist of $94 \mathrm{wt} . \%$ bio content determined as indicated in ASTM D6866 by the manufacturer. They tried to evaluate coupling agents' effects on fiber-matrix interactions. The four receipts were used in a twin-screw extruder. The addition of short fibers to of Cortaderia selloana to bio-based high density $P E$ results in a significant increase in stiffness, while even with relatively high fiber load (30 wt.\% by weight) [19]. Kumre A., et al. (2017) made a review work on mechanical specifications of sisal glass fiber reinforced polymer composites. In their study, the natural fiber polymer composites were analyzed with the glass fiber to raise the mechanical specifications of composite. The mechanical properties have increased by incorporating the glass into the sisal fiber epoxy polymer composite. It also increased the moisture resistance of sisal fiber. The tensile strength of the epoxy has not been improved by the reinforcement of sisal fibers. On the contrary, the tensile modulus, flexural and impact properties have been improved.

NFTC are being used in many industries, because of their extra advantages. These advantages are specific strength, low weight and cost, high mechanical specifications, bio-degradable and ecologically friendly characteristics [20]. Lörcks J. (1997) investigated the compostable starch-based polymers detailly [21]. Glass fiber reinforced polymers are mixed with natural fibers to improve their technological properties and engineering applications by Sanjay MR. et al. (2015). The authors presented a wide review on the subject of mechanical properties of natural glass fiber polymer composites in their work [22]. Jumaidin R. et al. (2017) were analyzed mechanical properties besides physical and thermal of some hybrid composites. Hybrid composites mechanical tests confirm improved tensile and flexural properties. The impact strength is reduced by using of Sugar Palm Fiber. Fracture surface showed a good fiber matrix adhesion. Moreover an effective stress-transfer from the fiber to the matrix was observed. The improvement in water resistance of hybrid composites was evident in all tests, i.e. water and moisture absorption, thickness-welling, water solubility [23]. 
Moreover, in some papers we can see a deep analysis of the investigation of NFTC mixing and manufacturing which are very important on productivity. In the cases of using up to $70 \%$ natural filler in weight, the composite could be used in industrial food packaging. Akdogan et al. (2012) worked the impacts of 3 different sized of beech wood flour, to the morphology and mechanical concerns of the composite materials at $60 \%$ wood filler in weight. A specially designed compounder was used at the experiments of compounding. The authors approximately $70 \%$ enhanced in tensile strength with the additive of under of $400 \mu \mathrm{m}$ particle sized wood scrap additive composite than neat Low Density Polyethylene (LDPE). Figure 2 gives the SEM micrographic captures of the fractured surfaces of the tensile test bars of composite [24].

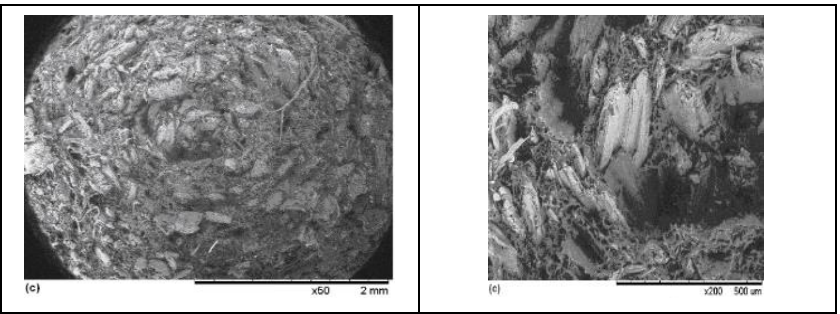

Figure 2: SEM micrographs of the fractured surfaces of NFTC [24].

The development of novel composite materials is still a vital concern of the industry. Surely, composite production design and proper manufacturing technologies are the key elements about development of new materials and composites. Although NFTC can be processed in existing cost advanced processing machines, practically using conventional machines to manufacture such complex composites causes some important processing problems. Even though manufacturers are well experienced in polymer production industry, using natural materials at high percentages is a still cause some production problems. So that productivities cannot be reaching at satisfactory levels. Moreover, such composites of course have different rheological characteristics than the regular polymers. This situ causes some primary process difficulties like high diehead pressures and energy consumption. Moreover, poor mechanical and thermal efficiencies are the other basic disadvantages. Finally, unacceptable manufacturing costs and low productivity rates will also be faced because of the mentioned difficulties and production problems.

Since NFTC are being used in many industries, because of their extra advantages, this paper firstly describes and classifies NFTC, secondly analyze production of NFTC by mentioning additives. Because of the increased environmental and cost concerns in an efficient compounding of NFTC, effective production solutions are required which also could overcome many production difficulties and supply high processing performances. The paper finally approaches about pulping and compounding processes for homogeneous mixing to get higher productivity and to supply better quality products by considering specially designed compounding extruders.

\section{Additives in production of NFTC materials}

The design, the usage and the disposal possibilities of bio-based polymers should be carefully determined because of the high usage potential of petroleum-based polymers. Thus, it would be possible to ensure adequate service conditions and appropriate valorization after their service life [25]. Compatibilization enhances the composite properties while increasing adhesion between the matrix and the additive. It reduces the interfacial tension and stabilizing morphology of the composite [26]. In order to be succeeded it; there are many methodologies could be used about compatibilization. The compatibility degree between the composite units could be improved by the addition of compatibilizer [27],[28]. Figure 3 shows the graphical representation of additive usage advantage in composite production industry.

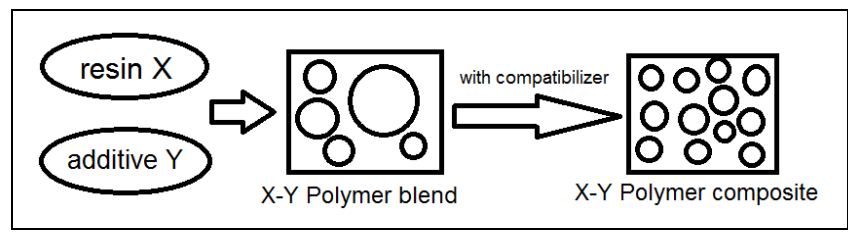

Figure 3: Additive usage in composite production.

Additive usage is a very popular application for wood based lignocellulosic polymer composites to enter new markets with more strong performance requirements and stability interests. Profile extrusion is used for the largest part of the market, e.g. floor boards; injection molding is also a good place. Extruded or injection molded part foaming is notable [9]. As common additives, the use of lubricants and colorants is commonly known. In addition to the use of other additives e.g. antimicrobials both for physical completeness and good view are popular. Moreover ultraviolet stabilizers for degradation protection and coupling agents are vital to improve life and strength expectations from products. Lubricants are typically used to increase output in extruded applications such as decking. In recent years, lubricants are being widely used in wood-polymer composites to improve processing performance, and many novel products supplying better compatibility with other additives and better processing advantages [29]. In some wood-polymer composites, alternative lubricants are available besides metallic stearate lubricants [30]. Increased fiber loading (up to $60 \%$ in weight) reduced the toughness but made the composites stiffer. Maleic anhydride addition increased the strength and stiffness [31]. One of the most effective and the most commonly used coupling agents for the starch-containing blend is Maleic Anhydride (MA). In the starch-polymer blends, both biodegradable polymers like Ethylene Vinyl Acetate (EVA) and PE, and nonbiodegradable polymers like Polybutylene Succinate (PBS) and PLA, were used as compatibilizer and functionalized by MA. In addition to the PLAs, a number of biodegradable aliphatic polyesters have been developed based on conventional polycondensation reactions [32]. Because of the sustainable importance of PLA, some Authors made review articles about their classifications, properties, productions, functions and applications in detail [33],[34]. A significant increase in strength was achieved by the addition of the compatibilizers. Modulation and elongation of the mix by the addition of compatibilizers were relatively less affected [35],[36].

Coupling agents in polymer composites has an importance in adhesion behavior of polymeric matrices and wood fibers. It improves compatibility. Coupling agents are currently popular in many industries especially in automotive and house goods to raise product performance. They aid in fiber dispersion. Fiber dispersion causes low water absorption and sustainable mechanical specifications. Flexural and tensile strengths and creep resistance at room temperature increase by coupling agents [9]. Coupling agents assist dispersion while helping foaming by improving melt strength [29]. Up to now, there are 
approximately more than 50 different type coupling agents are being used either in composite production industries and research works areas. These agents are called organic and inorganic as groups. Organic substances are more preferred than inorganic agents. Because they have much stronger adhesion capability than the inorganic agents. The most known coupling agents are isocyanates, silanes and anhydrides. The coupling agents are generally coated on the surface of wood fiber, polymer or both, by coupling, wetting or spraying [37]. Foaming of wood-polymer composite is very important. The basic advantages of foaming are weight, durability and costs. Additionally, foaming aids better stiffness and supplies easy cutting and fastening operations [29]. Foaming by lubricants helps to settle a cellular interior structure by allowing composites to act as real wood. Component density and cycling times reduce by foaming it also improves stiffness and performance with wood-working tools and fasteners. At the end, process would be improved [8]. Reduced weight makes wood-polymer composite easier to use in current and novel applications. The reduced weight facilitates make the use of wood-polymer composite both in existing applications and in new application areas such as fencing. It is easy to foam amorphous polymers because of their good foaming power. Due to their poor strength and typical calcium stearate integrant it is difficult to foam PP and PE. Because calcium stearate acts as a de-foamer agent. Foaming agent performance is dependent on the mixing ability, control and pressurizes temperatures [38]. It is also important to choose a compatible lubricant because some polar lubricants act as de-foamers. Water aim in many products is a fundamental disadvantage for foamed wood-polymer composite [29].

Lately, many methods were conducted in composite mixing to use lignocellulosic materials as an input. For this purpose, many researchers wrote articles on the reaction of wood flour with different alcohols. Researchers need alternative solutions against conventional pulping processes for wood pretreatment. At that point, solvent pulping method shows vital role to solve the lignin into the lignocellulosic content supplying better rheological specifications [39],[40]. Defibrated wood structure can be obtained by chemical pre-treatment. Wood particles with the highest aspect ratio are produced from preprocessed wood chips which have been extracted from composite and have the highest flexural strength and impact properties [41]. Pelletizing of the cellulose fibers helps to achieve sustainable feeding of extruder which supply highly filled cellulose fiber PP composites manufacturing is possible [31].

In order to overcome many processing problems causing unsatisfied productivity and product quality, lignocellulosic material should be pre-processed like pulping and pretreatment in place of using them directly in composite production [42]. Over the last decades some authors tried to perform lignocellulosic materials with alcohol like Glycerol [43],[44].

\section{Experimental works on production technologies}

The conventional extruding machines cannot be used in the NFTC manufacturing directly. Because of many production difficulties of these composites the machines need to be specifically re-designed. High mixing capability and some chemical lubrication and coupling additives are required for common conventional extruders when they are going to be used especially for lignocellulosic material reinforced composite production. Lignocellulosic polymer composite could be compounded with the related additives before manufacturing to overcome production difficulties.

Yu L. (2006) et al. described the blends progresses from different kinds of polymers. The first was the natural polymers, like protein and cellulose; the second was the synthetic polymers such as polylactic acid; and the third one was polymers from microbial fermentation. They are determined on potential applications. Multilayer co-extrusion is to combine the properties of two or more polymers into a single multilayer structure. It is a commonly used application in recent years [45]. Reactive extrusion (REx) technique of especially renewable and petrochemical sources of aliphatic polyesters based on the design and development of biodegradable polymeric materials is intended to examine how it can participate by Raquez J.M et al. in 2006 [46]. Recently, there are spectacular works on, reactive extrusion to introduce a variety of functional groups into biopolymer chains especially for composite products used in food and packaging industries [47]-[49].

Lou CW. et al. (2007) also worked on thermoplastic composites from blending virgin PET and PP pellets with the bamboo charcoal. Compounding and then injection molding processes were used. The results indicated that the mechanical properties of the PET/PPext (extrusion grade polypropylene) composites were better than that of the PET/PPinj (injection grade polypropylene). With $20 \%$ polyester, the mechanical properties of the PET/PPinj composite were not significantly influenced by the addition of bamboo charcoal [50]. Jayaraman K, Halliwell R. (2009) experienced with some composites consisting of fibers from flax plant of New Zealand, known as Maori, and some second hand plastics by injection molding. The tensile and impact properties of the Harakeke fiber-waste composite material shows remarkable increase compared to the waste plastic mixture. Thermoformed composites have been assessed [51].

New production procedures are based on some technologies of mixing the extrusion and the reaction extrusion processes. It leads to appropriate plastic raw materials optimized in the composite manufacturing industry using existing production lines that can be further processed into packaging materials, textiles and consumables.

In the conducted experiments of this paper, we used beech wood flour as reinforcement for polymer composite. At first wood flour was processed by $10 \% \mathrm{Na}_{2} \mathrm{SO}_{3}$ (w/w) included solution than it is approximately $15 \%$ grinded before the extrusion for a consistent feeding. The pre-treated wood flour was delivered to the fluidized bed by the screw in the first feed hopper to mix with PE which was delivered by the screw in the second feed hopper of the compounding extrusion for NFTC process. The additives are slip and anti-blocking agent (1 wt.\%) and coupling agent $(1 \mathrm{wt} . \%)$. After that, the polymer resin and the wood flour are mixed. The homogeneous mixing is supplied by the screw. The screw processed at low squeezing and at high mixing rates. Figure 4 gives the technical drawing of the used compounder in the experiments. 


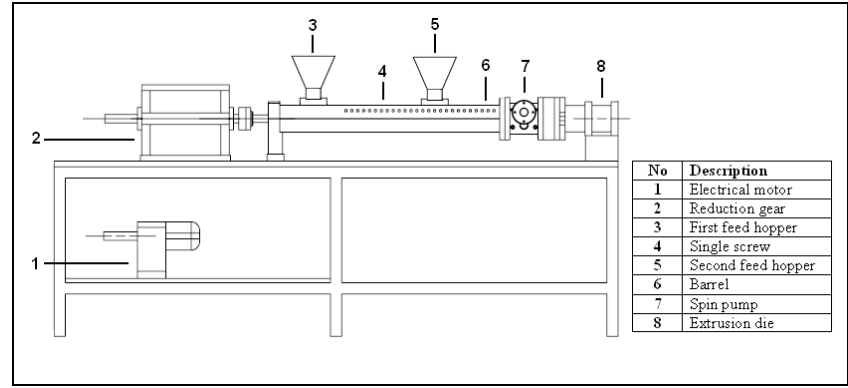

Figure 4: Technical drawing of the compounding extruder

[52].

At the end, compound is pressurized by the gear pump of the machine. It provides to manufacture the final profile from the die head. The machine has four different heating zones. Heating zone temperatures, angular velocity during the process and the produced torque are given in Table 2 as the process conditions in detail. The product output rate reached at almost $2 \mathrm{~kg} / \mathrm{h}$ by the help of pre-treatment process of the wood flour supplying consistent feeding. Additionally, the compounder machine process improvements like proper angular velocity and spin pump power were helped to raise the process performance.

Tablo 2: Extrusion process details.

\begin{tabular}{ccccccc}
\hline \multicolumn{3}{c}{$\begin{array}{c}\text { Heating zones } \\
\text { (C) }\end{array}$} & $\begin{array}{c}\text { Angular } \\
\text { velocity } \\
\text { (rpm) }\end{array}$ & $\begin{array}{c}\text { Torque } \\
\text { (Nm) }\end{array}$ & $\begin{array}{c}\text { Output } \\
\text { Rate } \\
\text { (kg/h) }\end{array}$ \\
\hline 120 & 135 & 140 & 140 & 30 & 40 & 1.98 \\
\hline
\end{tabular}

\section{Conclusions}

Natural fiber reinforcement has gained attention in polymers as a result of increasing cost of petroleum products. Composite production of renewable materials has a big amount of care due to the environmental concerns. Using biodegradable and renewable resources was an essential innovation. Therefore, composite materials consisting of natural fibers and waste plastics will result in the reduction of plastic wastes and the use of fibers from renewable sources.

However, because of the productibility concerns of the industry, natural fiber reinforcement percentage of NFTC had to be limited. Manufacturers must re-construct the conventional extruders as compounder style extruders to process NFTC easily. Improvements should be made especially on original screw constructions.

Nowadays, some commercial chemical lubrications and additives are popular for NFTC production to handle the local agglomerations on the composite. The addition of coupling agents during composite processing to improve the interfacial adhesion between the matrix and additive is another effective strategy.

Lately, many methods are in composite production to add lignocellulosic materials as input. For this purpose, many researchers wrote receipts on the reaction of wood flour with different alcohols for better processing performances. Solvent solution has a critical role as an alternative solution. The use of pre-treated wood flour raises the process capability and the mechanical properties of the NFTC.

Most of the composite materials are of course suitable for home, trim and board designs. But, the natural fiber usage especially in the automotive and aerospace sectors is drawing attention with the increasing number of applications.

This paper details of each step of the NFTC production such as process design, pre-treatments and manufacturing. It answers almost all required needs for continuous processing of NFTC products.

\section{Kaynaklar}

[1] Muthuraj R, Misra M, Mohanty AK. Studies on mechanical, thermal, and morphological characteristics of biocomposites from biodegradable polymer blends and natural fibers. Editors: Misra M, Pander J, Mohanty A. Biocomposites: Design and Mechanical Performance, 93-140, Canada, Woodhead Publishing, 2015.

[2] Sanjay MR, Arpitha GR, Yogesha B. "Study on mechanical properties of natural-glass fibre reinforced polymer hybrid". Materials Today: Proceedings, 2(4-5), 2959-2967, 2015.

[3] Imre B, Pukánszky B. "Recent advances in bio-based polymers and composites: Preface to the BiPoCo 2012 Special Section". European Polymer Journal, 49(6), 1146-1150, 2013.

[4] Imre B, Pukánszky B. "Compatibilization in bio-based and biodegradable polymer blends". European Polymer Journal, 49(6), 1215-1233, 2013.

[5] Naseem A, Tabasum S, Zia KM, Zuber M, Ali M, Noreen A. "Lignin-derivatives based polymers, blends and composites: A review". International Journal of Biological Macromolecules, 93, 296-313, 2016.

[6] Jiang L, Zhang J. Biodegradable and Biobased Polymers. Editor: Kutz M. Applied Plastics Engineering Handbook, 127-143, Norwich, NY, William Andrew Publishing, 2017.

[7] Jian L, Huang J, Qian J, Chen F, Zhang J, Wolcott MP, Zhu Y. "Study of Poly (3-hydroxybutyrate-co-3-hydroxyvalerate) (PHBV)/Bamboo Pulp Fiber Composites: Effects of Nucleation Agent and Compatibilizer". Journal of Polymers and the Environment, 16(2), 83-93, 2008.

[8] Markarian J. "Additive development aid growth in wood plastic composites". Plastics Additives \& Compounding, 4(11), 18-21, 2002.

[9] Pritchard G. "Two technologies merge: wood plastic composites". ReinforcedPlastics, 48(6), 21-29, 2004.

[10] Sykacek E, Hrabalova M, Frech H, Mundigler N. "Extrusion of five biopolymers reinforced with increasing wood flour concentration on a production machine, injection moulding and mechanical performance". Composites: Part A, 40(8), 1272-1282, 2009.

[11] Nygard P, Tanem BS, Karlsen T, Brachet P, Leinsvang B. "Extrusion-Based wood fiber-pp composites: wood powder and pelletized wood fibers-a comparative study". Composites Science and Technology, 68(15-16), 3418-3424, 2008.

[12] Danyadi L, Janecska T, Szabo Z, Nagy G, Moczo J, Pukanszky B. "Wood flour filled PP composites: Compatibilization and adhesion". Composites Science and Technology, 67(13), 2838-2846, 2007.

[13] Bledzki A, Letman M, Viksne R, Rence L. "A comparison of compounding processes and wood type for wood fibre-PP composites". Composites Part A, 36(6), 789-797, 2005. 
[14] Sykacek E, Hrabalova M, Frech H, Mundigler N. "Extrusion of five biopolymers reinforced with increasing wood flour concentration on a production machine, injection moulding and mechanical performance". Composites: Part A, 40(8), 1272-1282, 2009.

[15] Yu L, Dean M, Li L, "Polymer blends and composites from renewable resources". Progress in Polymer Science, 31(6), 576-602, 2006.

[16] Keener TJ, Stuart RK, Brown TK. "Maleated coupling agents for natural fiber composites". Composites Part A: Applied Science and Manufacturing, 35(3), 357-362, 2004.

[17] Nourbakhsh A, Karegarfard A, Ashori A, Nourbakhsh A. "Effects of particle size and coupling agent concentration on mechanical properties of particulate-filled polymer composites". Journal of Thermoplastic Composite Materials, 23(2), 169-174, 2010.

[18] Arrieta MP, López J, Ferrándiz S, Peltzer MA. "Characterization of PLA-limonene blends for food packaging applications”. Polymer Testing, 32(4), 760-767, 2013.

[19] Jord_a-Vilaplana A, Carbonell-Verdú A, Samper MD, Pop A, Garcia-Sanoguera D. "Development and characterization of a new natural fiber reinforced thermoplastic (NFRP) with Cortaderia selloana (Pampa grass) short fibers". Composites Science and Technology, 145, 1-9, 2017.

[20] Kumre A, Rana RS, Purohit R. "A Review on mechanical property of sisal glass fiber reinforced polymer composites". Materials Today: Proceedings, 4(2), 3466-3476, 2017.

[21] Lörcks J. "Properties and applications of compostable starch-based plastic material". Polymer Degradarion and Stability, 59(1-3), 245-249, 1998.

[22] Sanjay MR, Arpitha GR, Yogesha B. "Study on mechanical properties of natural-glass fibre reinforced polymer hybrid composites: a review". Materials Today: Proceedings, 2(4-5), 2959-2967, 2015.

[23] Jumaidin R, Sapuan SM, Jawaid M, Ishak MR, Sahari J. "Thermal, mechanical, and physical properties of seaweed/sugar palmfibre reinforced thermoplastic sugar palm Starch/Agar hybrid composites". International Journal of Biological Macromolecules, 97, 606-615, 2017.

[24] Akdoğan A, Vanlı AS. "Material characterization of different dimensioned wood particle reinforced polymer composites". Journal of Thermoplastic Composite Materials, 26(9), 1237-1248, 2013.

[25] Badia JD, Gil-Castell 0, Ribes-Greus A. "Long-term properties and end-of-life of polymers from renewable resources". Polymer Degradation and Stability, 137, 35-57, 2017.

[26] Ray SS, Pouliot S, Bousmina M, Utracki LA. "Role of organically modified layered silicate as an active interfacial modifier in immiscible polystyrene/polypropylene blends". Polymer, 45(25), 8403-8413, 2004.

[27] Gu SY, Zhang K, Ren J, Zhan H. "Melt rheology of polylactide/poly(butylenes adipate-co-terephthalate) blends, Carbohydrate". Polymers 74, 79-85, 2008.

[28] Marten E, Muller RJ, Deckwer WD. "Studies on the enzymatic hydrolysis of polyesters. II. Aliphatic-aromatic copolyesters". Polymer Degradation and Stability, 88(3), 371-381, 2005.

[29] Markarian J. "Wood-plastic composites: current trends in materials and processing". Plastics Additives \& Compounding, 7(5), 20-26, 2005.
[30] Markarian J. "Process modifiers improve output and cost competitiveness". Plastics Additives \& Compounding, 8(6), 20-23, 2006.

[31] Bengtsson M, Baillif ML, Oksman K. "Extrusion and mechanical properties of highly filled cellulose fibrepolypropylene composites". Composites: Part A, 38(8), 1922-1931, 2007.

[32] Raquez JM, Degée P, Nabarb Y, Narayan R, Dubois P. "Biodegradable materials by reactive extrusion: from catalyzed polymerization to functionalization and blend compatibilization". Comptes Rendus Chimie, 9(11-12), 1370-1379, 2006.

[33] Murariu M, Dubois P. "PLA composites: From production to properties". Advanced Drug Delivery Reviews, 107, 17-46, 2016.

[34] Farah S, Anderson DG, Langer R. "Physical and mechanical properties of PLA, and their functions in widespread applications-a comprehensive review". Advanced Drug Delivery Reviews, 107, 367-392, 2016.

[35] Mani R, Bhattacharya M. "Properties of injection moulded starch/synthetic polymer blends-III. Effect of Amylopectin to Amylose ratio in starch". European Polymer Journal, 34(10),1467-1475, 1998.

[36] Mani R, Bhattacharya M. "Properties of injection moulded blends of starch and modified biodegradable polyesters". European Polymer Journal, 37(3), 515-526, 2001.

[37] Cetin NS, Alma MH, Basturk MA. "Chemical agents and methods providing compatibility between ligno cellulosic fibers and synthetic polymer to obtain new composites". Journal of Science and Engineering, 3(2), 58-68, 2000.

[38] Reedy M. "New chemical foaming agents expand wood/plastic composite market". Plastics Additives and Compounding, 4(5), 24-26, 2002.

[39] Law KN, Kokta BV, Mao CB. "Fibre morphology and sodasulphite pulping of switchgrass". Bioresource Technology, 77(1), 1-7, 2001.

[40] Akhtar M, Scott G, Swaney R, Shipley, D. "Biomechanical pulping: a mill-scale evaluation". Resource Conservation and Recycling, 28(3-4), 241-252, 2000.

[41] Hietala M, Samuelsson E, Niinimäki J, Oksman K. "The effect of pre-softened wood chips on wood fibre aspect ratio and mechanical properties of wood-polymer composites". Composites: Part A, 42(12), 2110-2116, 2011.

[42] Sarul IT, Akdogan A, Koyun A. "Alternative production methods for lignocellulosic composite materials". Journal of Thermoplastic Composite Materials, 23(3), 375-384, 2010.

[43] Demirbas A. "Aqueous glycerol delignification of wood chips and ground wood". Biosource Technology, 63(2), 179-185, 1998.

[44] Kücük M, Demirbas A. "Kinetic study on hydrolysis of biomass (Ailanthus altissima chips) by using Alkalineglycerol solution". Energy Conservation\&Management, 40(13), 1397-1403, 1999.

[45] Yu L, Dean K, Li L. "Polymer blends and composites from renewable resources". Progress in Polymer Science, 31(6), 576-602, 2006.

[46] Gila BM, Songa SW, Leea JH, Jeona J, Leea KH, Wie JJ. "Introduction of primary chemical bonding in lignin-based PP composites for mechanical reinforcement via reactive extrusion". Composites Part B: Engineering, 165, 510-515, 2019. 
[47] Luoa G, Liua G, Chena Y, Liangb W, Liub G, Niua Y, Lia G. "High performance glass fiber reinforced polypropylene realized by reactive extrusion technology". Composites Science and Technology, 165, 198-205, 2018.

[48] Quiles-Carrilloa L, Montanesa N, Sammonb C, Balarta R, Torres-Giner S. "Compatibilization of highly sustainable polylactide/almond shell flour composites by reactive extrusion with maleinized linseed oil”. Industrial Crops \& Products, 111, 878-888, 2018.

[49] Lou CW, Lin CW, Lei CH, Su KH, Hsu CH, Liu ZH, Lin JH. "PET/PP blend with bamboo charcoal to produce functional composites". Journal of Materials Processing Technology, (192-193), 428-433, 2007.
[50] Jayaraman K, Halliwell R. "Harakeke (phormium tenax) fibre-waste plastics blend composites processed by screwless extrusion". Composites: Part B, 40(7), 645-649, 2009.

[51] Akdogan A, Vanlı AS. Wood-Polymer Composites. Editor: Concu G. Wood Civil Engineering, 149-170, London, England, InTech Open Access Publishing, 2017. 